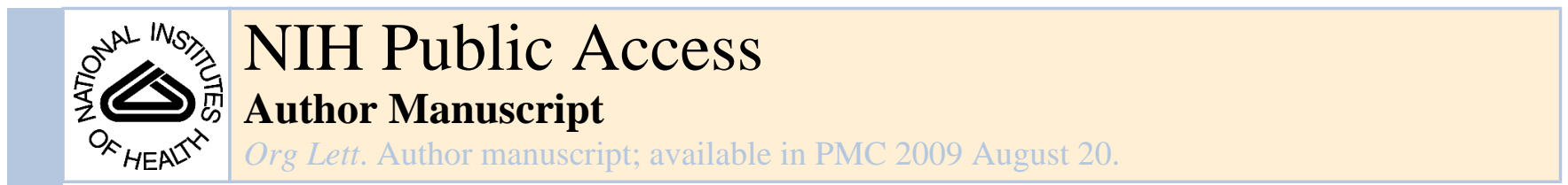

Published in final edited form as:

Org Lett. 2007 February 1; 9(3): 437-440. doi:10.1021/ol062804a.

\title{
Asymmetric Synthesis of Diastereometric
}

\section{Diaminohepatanetetraols. A Proposal for the Configuration of (+)-}

\section{Zwittermicin A}

\author{
Evan W. Rogers ${ }^{\dagger}$ and Tadeusz F. Molinski ${ }^{\dagger}$ \\ Department of Chemistry and Biochemistry, University of California, San Diego, 9500 Gilman Drive, \\ La Jolla, California 92093, and Department of Chemistry, University of California, Davis, One \\ Shields Avenue, Davis, California 95616
}

\section{Abstract<smiles>NC(=O)NC[C@@H](NC(=O)[C@@H](O)[C@H](O)[C@H](N)[C@H](O)C[C@H](O)[C@H](N)CO)C(N)=O</smiles> \\ Zwittermicin A (1)}

A proposed absolute configuration for the 7 stereocenters in (+)-zwittermicin A is described based on asymmetric synthesis of six diastereomeric 2,6-diamino-1,3,5,7-heptanetetraols corresponding to the $\mathrm{C} 9-\mathrm{C} 15$ segment, pair-wise ${ }^{13} \mathrm{C}$ NMR chemical shift difference analysis of the models with the natural product, interpretation of enantiospecificity of serine loading domain of the zwittermicin A biosynthetic gene cluster, and degradation of the natural product.

(+)-Zwittermicin A (1), a water-soluble natural antibiotic isolated from fermentation of the soil-borne bacterium Bacillus cereus. ${ }^{1}$ Compound $\mathbf{1}$ is of significant interest for control of crop diseases both as an antifungal agent and an adjuvant with BT toxin for biocontrol. ${ }^{2}$

Despite the appearance of its structure, $\mathbf{1}$ is not a sugar, but a polyketide derived from a serine starter unit followed by consecutive additions of aminomalonate, malonate and two hydroxymalonates, each with a concomitant loss of $\mathrm{CO}_{2} \cdot{ }^{3}$ Although the original isolation and structure elucidation - with partial relative configuration at $\mathrm{C} 8$-C10 - were reported twelve years ago, the complete relative and absolute configuration remained unsolved. Neither the

tmolinski@ucsd.edu.

${ }^{\dagger}$ Present address, UCSD

Supporting Information Available: Experimental procedures, X-ray data for 22 and selected ${ }^{1} \mathrm{H}$ and ${ }^{13} \mathrm{C}$ NMR. This material is available free of charge via the Internet at http://pubs.acs.org. 
natural product or any of the derivatives prepared to date exhibit crystallinity suitable for Xray analysis. Applications of ' $J$-based' NMR methods for assignment of relative configuration in $\mathbf{1}$ failed due to lack of stereorelayed scalar couplings across the $\mathrm{C} 12$ methylene group; a problem related to the stereotopicity of the corresponding ${ }^{1} \mathrm{H}$ NMR signals (vide infra). ${ }^{4}$ Thus, this rare diamino-polyol represents a significant challenge for stereochemical elucidation. Herein, we assign the configuration of $\mathbf{1}$ using a combination of model synthesis, paired ${ }^{13} \mathrm{C}$ NMR chemical shift comparisons, Marfey's analyis, ${ }^{5}$ and a bioinformatic interpretation of the gene sequence for zwittermicin A synthase. ${ }^{3}$ A flexible preparation of the C9-C15 core of $\mathbf{1}$ is revealed that exploits Miyashita conditions for regioselective 2,3-epoxy-1-alkanol ring opening by azide and is amenable for the total synthesis of the natural product.

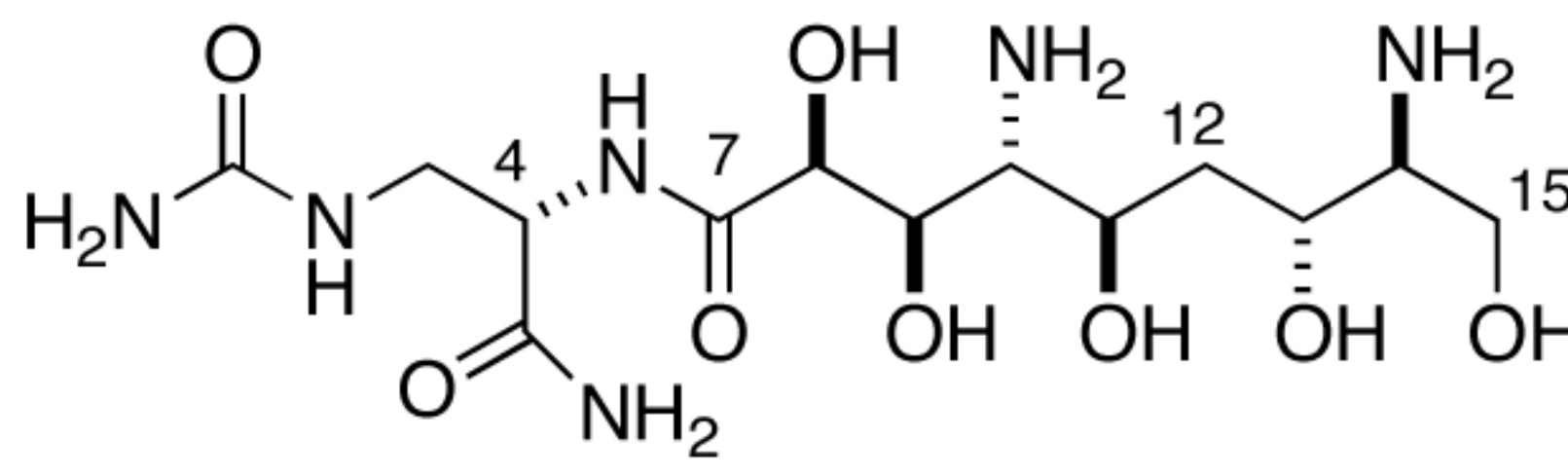

\section{Zwittermicin A (1)}

The pseudo-symmetry present in the C9-C15 portion of 1 suggested a unified strategy for construction of six model compounds that embody all possible relative configurations for the pair of diads, C10,11 and C13,14.

With the exception of $\mathrm{C} 11$, the ${ }^{13} \mathrm{C}$ NMR chemical shifts of these remote centers are expected to be relatively independent of the remainder of the molecule. Consequently, pair-wise comparison of chemical shifts in the models with the corresponding values in 1 should converge upon a unique configurational assignment.

The six models 2-7 were synthesized starting with serine (Scheme 1). $O$-TBS- $N, N$ -

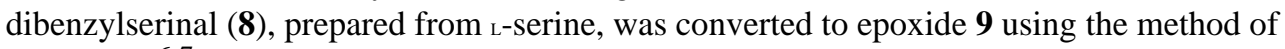
Concellón. ${ }^{6,7}$ Carbon chain extension of 9 by a $\mathrm{BF}_{3}{ }^{\bullet} \mathrm{Et}_{2} \mathrm{O}$-mediated epoxide opening with the anion derived from $O$-TBS propargyl ether afforded 10. Protecting group adjustment followed by Red-Al reduction of the triple bond gave $E$-olefin 11, which was treated with $m$-CPBA to give diastereomeric epoxides $\mathbf{1 2}$ and $\mathbf{1 3}$ in a ratio of 1:1.8.

Separation of the diastereomers required protection of the primary alcohol and HPLC separation followed by deprotection to give the pure epoxides. Regioselective elaboration of the contiguous 2-amino-1,3-diol motif was projected based on Miyashita's boron-directed azide opening of 1,2-epoxy-alkanols. ${ }^{8}$ In the event, separate azide opening of epoxides $\mathbf{1 2}$ and 13 using Miyashita's method provided 1,3-diols 14 (dr 9:1) and 15 ( $\mathrm{dr}$ 2.3:1), respectively, in good yields. ${ }^{9}$ Acid catalyzed deprotection of $\mathbf{1 4}$ and 15, with concomitant hydrogenolysis of the benzyl and azido groups afforded models $\mathbf{2}$ and $\mathbf{3}$, respectively, as their hydrochloride salts. The configurations of the two diastereomers were readily apparent by ${ }^{1} \mathrm{H}$ and ${ }^{13} \mathrm{C}$ NMR spectroscopy which revealed $C_{2 \mathrm{v}}$ symmetry in $\mathbf{2}$. 
The remaining four models were synthesized from the ${ }_{\mathrm{L}}$-serine methyl ester derivative 16 (Scheme 2) using the complementary syn-selective epoxide formation ${ }^{7}$ to provide $\mathbf{1 7}$, the $\mathrm{C} 2$ epimer of 9 . Chain extension of $\mathbf{1 7}$ was achieved as before to give propargyl alcohol $\mathbf{1 8}$ which was separately converted to $E$ - and $Z$-allylic alcohols 19 and 20 by Red-Al reduction or hydrogenation over Lindlar catalyst, respectively. Epoxidation of olefin 19 using $m$-CPBA was less successful due to the lability of the diastereomeric products, however, oxidation of 19 with methyltrioxorhenium gave a mixture of distereomeric epoxides which was carried forward using Miyashita's method followed by acetonide protection to give azides $\mathbf{2 1}$ and $\mathbf{2 2}$. Since neither of the two diaminotetraols anticipated from conversion of $\mathbf{2 1}$ and $\mathbf{2 2}$ were expected to show symmetry ( $C_{1}$ space group), the configurational assignments of these molecules from NMR were in doubt. Fortunately, azide 22 crystallized as colorless needles (m.p. $138^{\circ} \mathrm{C}$ ) and $\mathrm{X}$-ray analysis (Figure 2) provided the configuration of the 4-substitued $(4 R, 5 S)-2,2-$ dimethyl-5-azidodioxane ring $[(13 R, 14 S)$, zwittermicin A numbering]. It follows that 21 is the $(4 S, 5 R)$-diastereomer.

To further verify stereochemical assignments of the models, azide $\mathbf{1 5}$ was converted to the acetonide 23 (Scheme 3). The ${ }^{1} \mathrm{H}$ NMR spectrum of $\mathbf{2 3}$ showed the expected large diaxial vicinal couplings $(\delta 4.14$, ddd, $J 10.4,8.0,2.4 \mathrm{~Hz} ; \delta 3.83$, ddd, $J=11.6,6.4,2.4 \mathrm{~Hz}$ ) for a syn-4,6-disubstituted 1,3-dioxane and large ${ }^{13} \mathrm{C}$ chemical shift differences for the gem $\mathrm{CH}_{3}$ signals of the isopropylidene group $\left(\delta 29.9\right.$, q; 19.7, q). ${ }^{10}$

Acid-catalyzed global deprotection and hydrogenolysis of $\mathbf{2 1}$ and $\mathbf{2 2}$ compounds provided models $\mathbf{4}$ and 5, respectively, as their $\mathrm{HCl}$ salts. Models $\mathbf{6}$ and $\mathbf{7}$ were synthesized from olefin 20 using the same approach.

The diastereomeric family of model compounds comprise two meso compounds ( 3 and $\mathbf{6})$, two $C_{2}$ isomers ( 2 and 7) and two isomers lacking symmetry $\left(C_{1}, 4\right.$ and 5). As expected, the ${ }^{1} \mathrm{H}$ NMR signal of the $\mathrm{C} 4$ methylene protons in each $C_{2}$ isomer (e.g. $2, \delta 1.66 \mathrm{~m}, 2 \mathrm{H}$ ) appeared as complex second-order multiplet owing to the fact that the $\mathrm{H} 4$ protons were chemical-shift equivalent but magnetically in-equivalent. Conversely, the 4- $\mathrm{CH}_{2}$ protons in the meso isomer 3 are both chemical shift inequivalent and magnetically inequivalent and appear as diastereotopic protons exhibiting a first-order $\mathrm{ABX}_{2}$ pattern $(\delta 1.79 \mathrm{dt} 1 \mathrm{H}, J=14.4,8.4 \mathrm{~Hz} ; \delta$ $1.84, \mathrm{dt}, 14.4,4.7 \mathrm{~Hz}, 1 \mathrm{H})$. Analogous patterns were observed for $C_{2}$-symmetrical 7 and meso-6. Interestingly, the ${ }^{1} \mathrm{H}$ NMR signal of corresponding $\mathrm{C} 12$ methylene group in $\mathbf{1}$ also exhibited a complex second order pattern $(400,500$ and $600 \mathrm{MHz})$ similar to those of 2 and 7, but dissimilar to the 4- $\mathrm{CH}_{2}$ signals of $\mathbf{3}$ and $\mathbf{6}$ of suggesting that the spin systems in $\mathbf{1}, \mathbf{2}$ and 7 reflected local $C_{2}$ or pseudo- $C_{2}$ symmetry, largely dictated by an anti-relationship of the $\mathrm{C} 11$ and $\mathrm{C} 13 \mathrm{OH}$ groups.

An unequivocal assignment of relative configuration for the diaminotetraol segement in 1 was made by pairwise comparisons of the differences in the ${ }^{13} \mathrm{C}$ chemical shifts $(\Delta \delta)$ for $\mathrm{C} 10-\mathrm{C} 15$ of $\mathbf{1}$ and model compounds (Figure 1). ${ }^{11}$ There are only six diastereomers of the symmetrically substituted diaminoheptanetetraol models but eight diastereomers of the C10-C15 segment in 1. To complete the comparison, the ${ }^{13} \mathrm{C} \delta$ assignments of $C_{1}$ isomers $\mathbf{4}$ and $\mathbf{5}$ were reversed to give the remaining two isomers - virtual compounds " $\mathbf{4 b}$ " and " $\mathbf{5 b}$ ". The $C_{2 \mathrm{v}}$ symmetric $\mathbf{2}$ is the only model compound with a close match to 1 for every carbon (Figure 1) except C9, which is the point of difference between $\mathbf{1}$ and the models and expected to show an 'outlying' $\Delta \delta$ in every case.

Importantly, the other $C_{2 \mathrm{v}}$ isomer 7 had the largest mismatch which secures confidence for assignment of erythro relationships in each of the C10,11 and C13,14 diads. Elimination of the mismatched meso isomers 3 and 6, as suggested by ${ }^{1} \mathrm{H}$ NMR and stereotopicity analysis of the $12-\mathrm{CH}_{2}$ signal (above), is now corroborated by ${ }^{13} \mathrm{C} \mathrm{NMR}$. 
Therefore, compounds $\mathbf{1}$ and $\mathbf{2}$ share the same relative configuration at the stereogenic centers corresponding to $\mathrm{C} 10, \mathrm{C} 11, \mathrm{C} 13$ and $\mathrm{C} 14$ of $\mathbf{1}$. The data in Figure 1, in conjunction with the relative configurations at $\mathrm{C} 8-\mathrm{C} 10^{1}$ now allow us to extend the assignment of relative configuration of $\mathbf{1}$ to $\mathrm{C} 8-\mathrm{C} 15$.

Although no direct evidence for the absolute configuration of C8-C15 is yet available, analysis of the published sequence of the gene cluster for biosynthesis of zwittermicin A highly suggests that the $\mathrm{C} 14$ shares the same configuration as L-serine. ${ }^{3}$ Zwittermicin A is synthesized by a hybrid polyketide synthase-nonribosomal peptide synthase (PKS-NRPS) that comprises nine open reading frames including a loading domain for the starter unit that is homologous with serine adenylation domains found in gene clusters for biosynthesis of iturin A and mycosubtilin. Since the proposed gene sequence for production of $\mathbf{1}$ shows $\mathrm{C} 13-\mathrm{C} 15$ originating from $\mathrm{L}$-serine and epimerase domains are absent, it is highly likely that $\mathrm{C} 14$ is $\mathrm{L}^{-}$and the absolute stereochemistry for C8-C14 in $\mathbf{1}$ is as depicted.

The absolute configuration at the remaining $\mathrm{C} 4$ stereocenter in $\mathbf{1}$ was determined as $4 S$ by Marfey's analysis..$^{5}$ Acid hydrolysis of authentic $\mathbf{1}\left(6 \mathrm{~N} \mathrm{HCl}, 24 \mathrm{~h}, 110^{\circ} \mathrm{C}\right)$ and derivatization of the products with 2,4-dinitrophenyl-5-fluoro-L-alaninamide (Marfey's reagent) under standard conditions, followed by analysis $\left(\mathrm{C}_{18}\right.$ HPLC-MS) gave one peak that matched the peak (coinjection, MS spectrum) obtained by similar treatment of commercially available (-)$(S)$ - $N^{3}$-ureido-2,3-diaminopropionic acid ( $S$-albizziin).

In conclusion we have assigned the configuration of 1 as $(4 S, 8 S, 9 R, 10 R, 11 R, 13 R, 14 S)$. using an integrated approach based on synthesis and pairwise comparisons with model compounds, Marfey's analysis, and published data. This sets the stage for completion of $\mathbf{1}$ by chain extension of a suitably protected derivative of $\mathbf{2}$ and attachment of the $N^{3}$-ureido-2,3-

diaminopropionamide side chain, which is the subject of current research in our laboratories.

\section{Supplementary Material}

Refer to Web version on PubMed Central for supplementary material.

\section{Acknowledgment}

We thank Mark Zabriskie (Oregon State University) for helpful discussions, and Entotech, Inc. (Davis, CA) for a sample of authentic zwittermicin A. X-ray analysis was carried out by A. Rheingold (UCSD). HRMS measurements were carried out by R. New (UC Riverside MS Facility), Y. Su (UC San Diego MS Facility), and the Scripps Center for Mass Spectrometry (La Jolla, CA). The UC Davis $400 \mathrm{MHz}$ NMR and LCMS were purchased with funds provided by instrument grants NSF CHE-9808183 and RR14701-01 respectively. This work was supported by a grant from the NIH (to TFM, RO1 AI39987) and a fellowship from the Ecotoxicology Lead Campus Program (to EWR, UC Davis).

\section{References}

(1)(a). He H, Silo-Suh LA, Handelsman J, Clardy J. Tetrahedron Lett 1994;35:2499. (b) Silo-Suh LA, Lethbridge BJ, Raffel SJ, He H, Clardy J, Handelsman J. Appl. Environ. Microbiol 1994;60:2023. [PubMed: 8031096]

(2)(a). Silo-Suh LA, Stabb EV, Raffel SJ, Handelsman J. Curr. Microbiol 1998;37:6. [PubMed: 9625782] (b) Broderick NA, Goodman RM, Raffa KF, Handelsman J. Environ. Entomol 2000;29:101. (c) Stohl EA, Brady SF, Clardy J, Handelsman J. J. Bacteriol 1999;181:5455. [PubMed: 10464220] (c) Broderick NA, Goodman RM, Raffa KF, Handelsman J. Environ. Entomol 2000;29:101.

(3)(a). Emmert EA, Kilmowicz AK, Thomas MG, Handelsman J. Appl. Environ. Microbiol 2004;70:104. [PubMed: 14711631] (b) Stohl EA, Milner JL, Handelsman J. Gene 1999;237:403. [PubMed: 10521664]

(4). Murata M, Nakamura H, Tachibana K. J. Org. Chem 1999;64:866. [PubMed: 11674159] HETLOC or $\mathrm{HMBC}$ experiments $\left(600 \mathrm{MHz}, \mathrm{D}_{2} \mathrm{O}\right)$ did not extract useful ${ }^{2,3} J_{\mathrm{CH}}$ couplings across the $\mathrm{C} 11$ - 
C12-C13 sequence, while ${ }^{1} \mathrm{H}-{ }^{1} \mathrm{H}$ couplings to the $\mathrm{C} 12$ methylene group showed second-order effects as discusssed later in the text.

(5). Marfey P. Carlsberg Res. Commun 1984;49:591.

(6)(a). Hulme AN, Montgomery CH, Henderson DK. Chem. Soc., Perkin. Trans. 1 2000:1837. (b) Laïb T, Chastanet J, Zhu J. J. Org. Chem 1998;63:1709.

(7). Concellón JM, Riego E, Rodríguez-Solla H, Plutín AM. J. Org. Chem 2001;66:8661. [PubMed: 11735555]

(8). Sasaki M, Tanino K, Hirai A, Miyashita M. Org. Lett 2003;5:1789. [PubMed: 12735778]

(9). Under standard conditions, in the absence of $\mathrm{B}(\mathrm{OMe})_{3}$ yields and regioselectivity were poor (e.g. 12-> 14, $\left(\mathrm{NH}_{4} \mathrm{Cl}, \mathrm{NaN}_{3}, \mathrm{DMF}, 44 \%\right.$, dr 1:1.4)

(10). Rychnovsky SD, Rogers B, Yang G. J. Org. Chem 1993;58:3511-3515.

(11). ${ }^{13} \mathrm{C}$ NMR measurements of the of the hydrochloride salts of $\mathbf{1}$ and models $\mathbf{2 - 7}$ were carried out under essentially identical conditions $\left(\mathrm{D}_{2} \mathrm{O}, 25^{\circ} \mathrm{C}\right)$ with internal $\mathrm{CH}_{3} \mathrm{CN}$ as reference. 


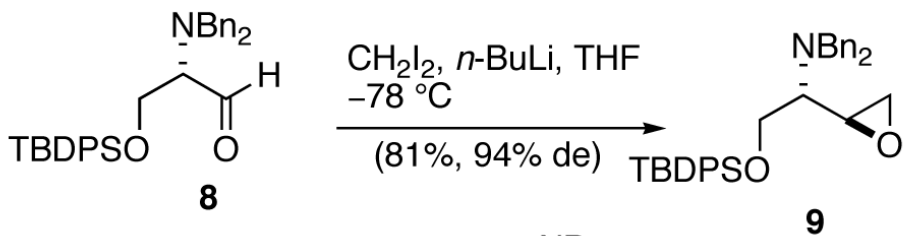

a) $\mathrm{HCCCH}_{2} \mathrm{OTBS}$

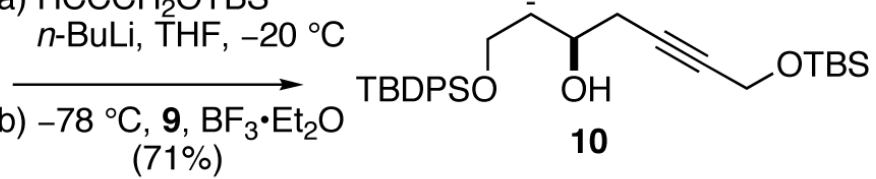

1) TBAF, THF, $-20{ }^{\circ} \mathrm{C}(97 \%)$

2) a) CSA, acetone, $\mathrm{Me}_{2} \mathrm{C}(\mathrm{OMe})_{2}$, reflux

b) THF:AcOH: $\mathrm{H}_{2} \mathrm{O} 9: 2: 1$ (79\%)<smiles>CCCC[C@@H]1OC(C)(C)OC[C@H]1CC/C=C/CO</smiles>

3) Red-Al, $\mathrm{Et}_{2} \mathrm{O}, 0^{\circ} \mathrm{C}(97 \%)$

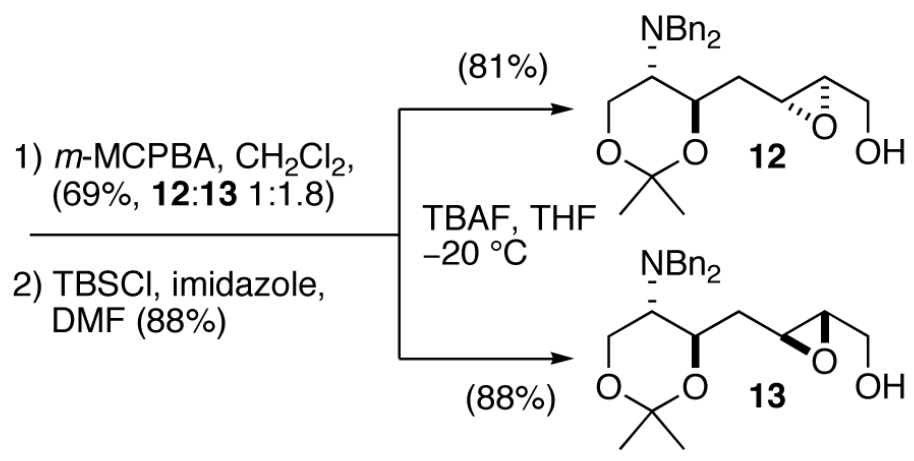

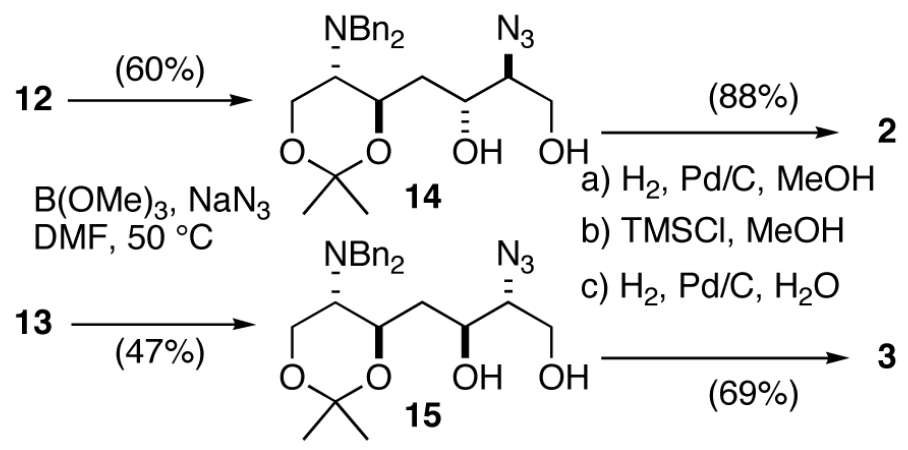

Scheme 1. 


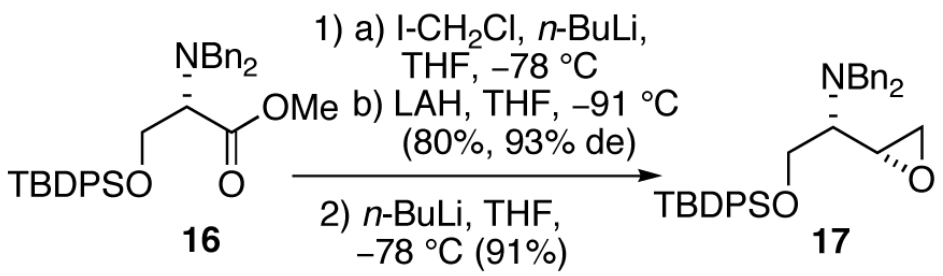

1) a) $\mathrm{HCCCH}_{2} \mathrm{OTBS}, n$-BuLI, THF, $-20^{\circ} \mathrm{C}$

b) $-78{ }^{\circ} \mathrm{C}, 17, \mathrm{BF}_{3} \cdot \mathrm{Et}_{2} \mathrm{O}(80 \%)$

2) TBAF, THF, $-20^{\circ} \mathrm{C}(82 \%)$

3) a) CSA, acetone, $\mathrm{Me}_{2} \mathrm{C}(\mathrm{OMe})_{2}$, reflux

b) THF:AcOH: $\mathrm{H}_{2} \mathrm{O} 9: 2: 1(80 \%)$

$\mathrm{NBn}_{2}$

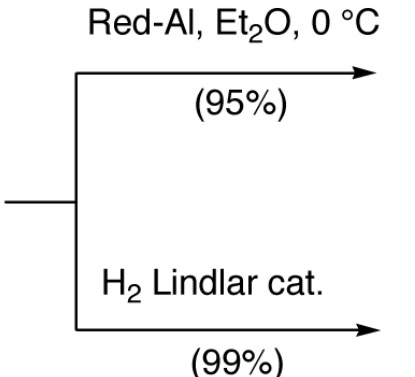<smiles>CC(C)(C)OC1(C)OC[C@H](C/C=C/CO)[C@@H](C/C=C/CO)O1</smiles>

1) pyridine, $\mathrm{MeReO}_{3}, \mathrm{H}_{2} \mathrm{O}_{2}$, $\mathrm{CH}_{2} \mathrm{Cl}_{2}$ (22\%, anti:syn 1:1.8)

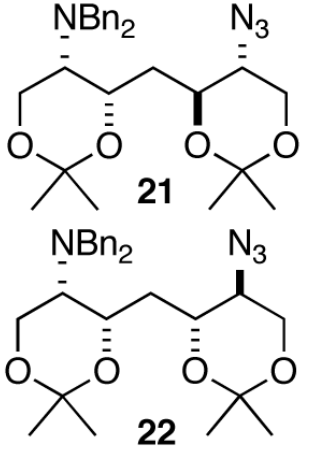

$21 \stackrel{(99 \%)}{\longrightarrow} 4$

a) $\mathrm{H}_{2}, \mathrm{Pd} / \mathrm{C}$, EtOH/hexane

b) $\mathrm{TMSCl}, \mathrm{MeOH}$

c) $\mathrm{H}_{2}, \mathrm{Pd} / \mathrm{C}, \mathrm{H}_{2} \mathrm{O}$

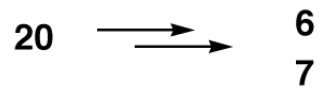

Scheme 2. 


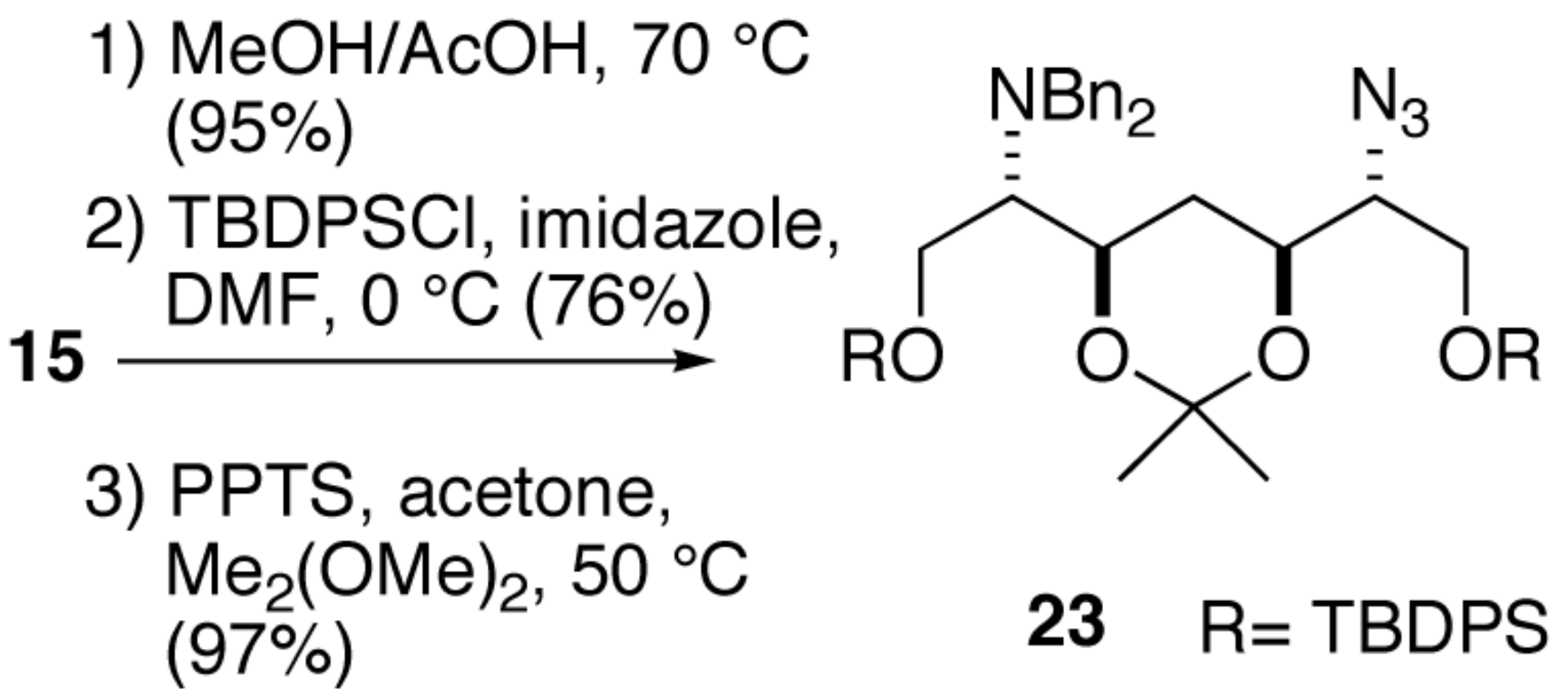

Scheme 3. 

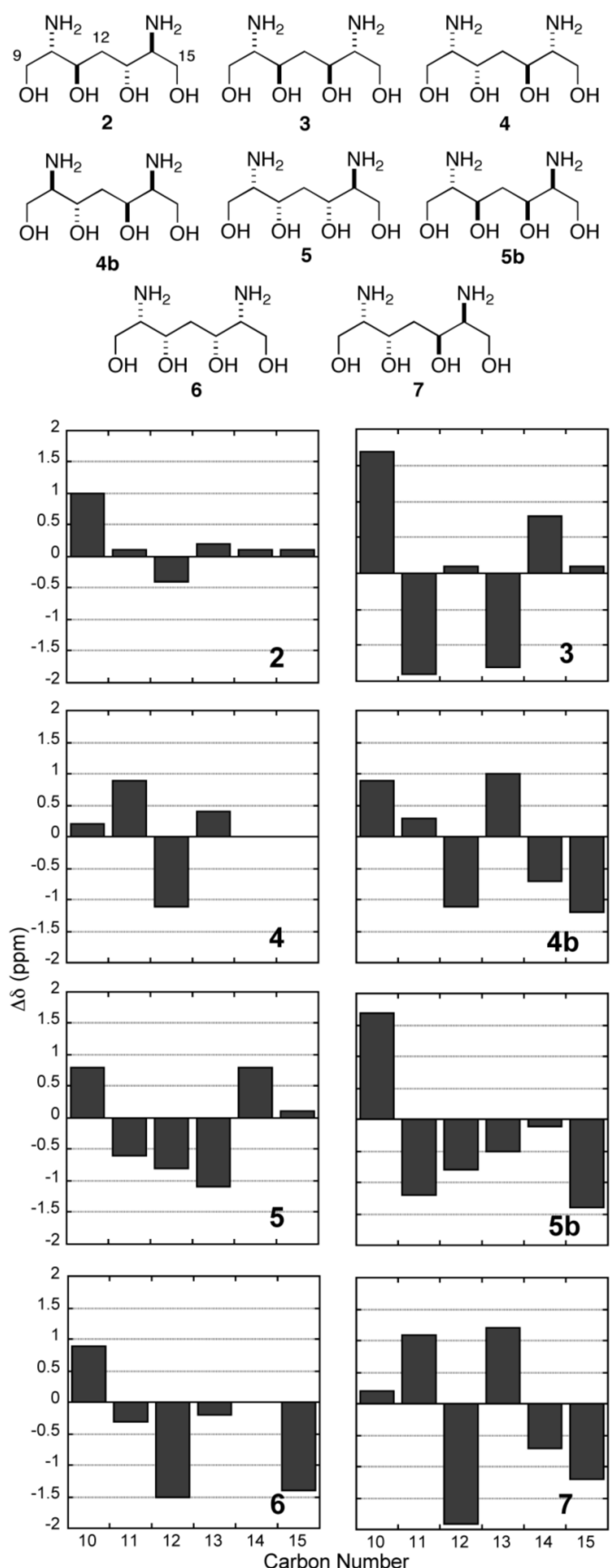

Figure 1.

${ }^{13} \mathrm{C}$ NMR $\left(100 \mathrm{MHz}, \mathrm{D}_{2} \mathrm{O}\right.$, ref. internal $\left.\mathrm{CH}_{3} \mathrm{CN}, \delta 1.47 \mathrm{ppm}\right) \Delta \delta$ values $\left(\delta_{\mathrm{C}}\right.$ model $\left.-\delta_{\mathrm{C}} \mathbf{1}\right)$ of model compounds 2-7. " $\mathbf{4 b}$ " and " $\mathbf{5 b}$ " are 'virtual isomers' of $\mathbf{4}$ and $\mathbf{5}$, respectively, by reversing the order of ${ }^{13} \mathrm{C} \delta$ assignments for the purpose of comparison with $\mathbf{1}$. 


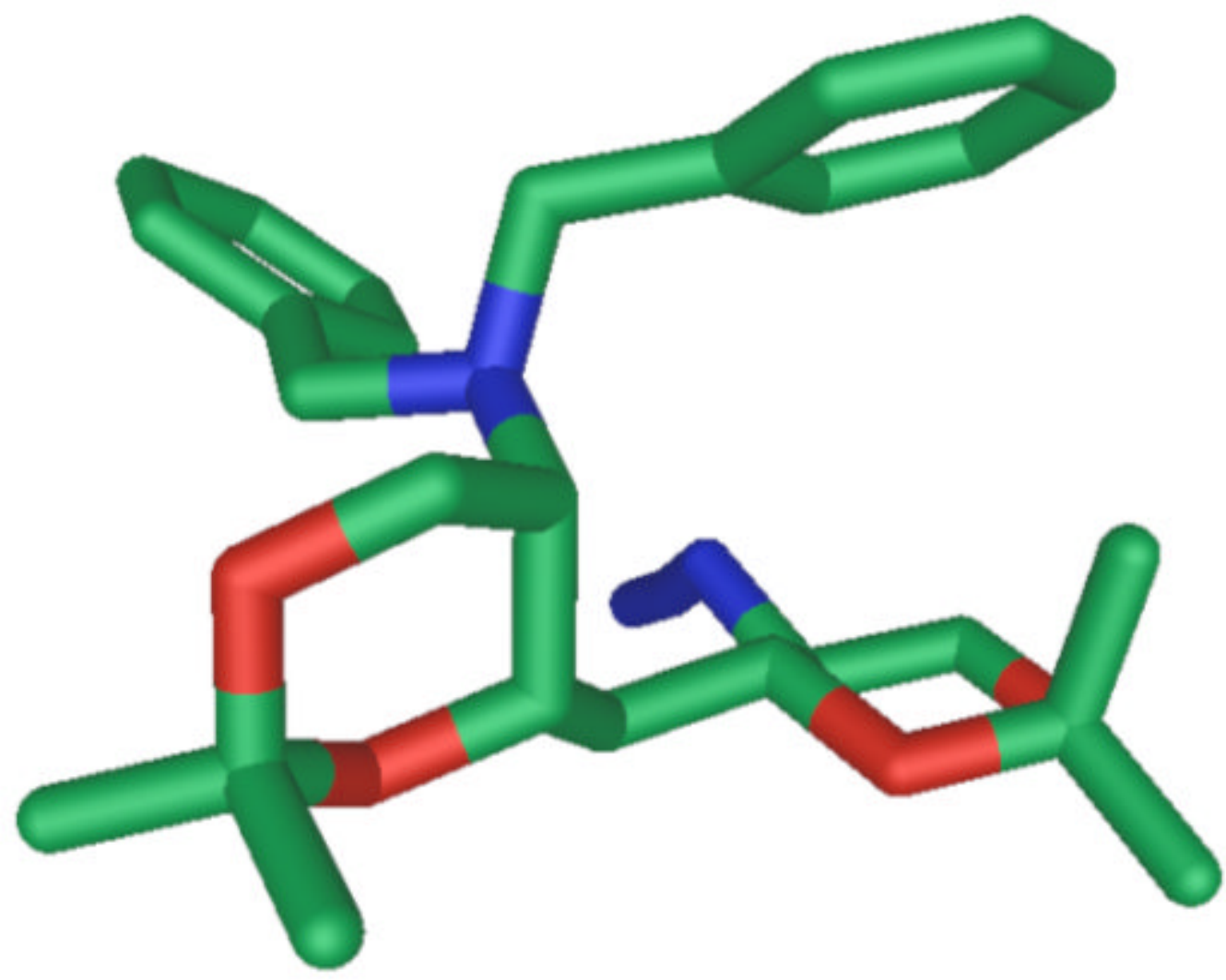

Figure 2.

$\mathrm{X}$-ray structure of $\mathbf{2 2}$. 